Abstract

\title{
Analysis of the Cytotoxic Effects of Eryngium billardieri Delar. Extracts on MCF7 Cell Line ${ }^{+}$
}

\author{
Leyla Paşayeva 1,*, Esra Köngül 1, Rojen Geylan ${ }^{1}$, Gökçe Şeker Karatoprak ${ }^{1}$ and Osman Tugay ${ }^{2}$ \\ 1 Department of Pharmacognosy, Faculty of Pharmacy, Erciyes University, Melikgazi 38030, Turkey \\ 2 Department of Biology Program of Botany, Faculty of Sciences, Selcuk University, Selçuklu 42250, Turkey \\ * Correspondence: leylapasayeva@hotmail.com; Tel.: +90-352-2076-666 \\ + Presented at the 2nd International Conference on Natural Products for Cancer Prevention and Therapy, \\ Kayseri, Turkey, 8-11 November 2017.
}

Published: 14 November 2017

\begin{abstract}
The Apiaceae (previously known as the Umbelliferae) is one of the largest plant families in the world. This family comprises approximately 450 genera and 3700 species worldwide. The members of this family are well known as vegetables, culinary and medicinal plants. Members of Apiaceae possess various compounds with many biological activities. Some of the main properties are ability to induce apoptosis, antibacterial, hepatoprotective, vaso-relaxant, cyclooxygenase inhibitory and antitumor activities. In this study, 70\% methanol extract prepared from the aerial parts of Eryngium billardieri, which belongs to Apiaceae family, and ethyl acetate, $n$-butanol fractions obtained from this extract were investigated by MTT method for cytotoxic effect on MCF7 (human breast cancer cell line) cell line. In result, the methanol extract was found more cytotoxic than fractions with $99.50 \mu \mathrm{g} / \mathrm{mL}$ IC50 value on MCF7 cell line.
\end{abstract}

Keywords: Eryngium billardieri; Apiaceae; cytotoxicity; MCF7

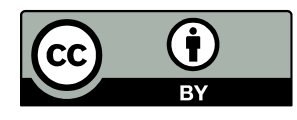

(C) 2017 by the authors. Licensee MDPI, Basel, Switzerland. This article is an open access article distributed under the terms and conditions of the Creative Commons Attribution (CC BY) license (http://creativecommons.org/licenses/by/4.0/). 